\title{
ALEKSANDER CHEOPECKI*
}

\author{
Uniwersytet Warszawski
}

\section{DEFINICJA PAPIERÓW WARTOŚCIOWYCH DŁUŻNYCH}

\section{WPROWADZENIE - POTRZEBA ZDEFINIOWANIA POJĘCIA PAPIERÓW WARTOŚCIOWYCH DŁUŻNYCH}

Podstawowym zagadnieniem analizowanym w tym artykule jest definicja papierów wartościowych dłużnych. Praktyczne zdefiniowanie pojęcia papierów wartościowych dłużnych jest konieczne, ponieważ pojęciem tym posługuje się ustawodawca w ważkich społecznie regulacjach. Przykładowo:

a) w art. 141 ustawy o organizacji i funkcjonowaniu funduszy emerytalnych ${ }^{1}$ papiery wartościowe dłużne są jednym ze źródeł lokat,

b) w art. 63 ustawy o działalności ubezpieczeniowej ${ }^{2}$ - papiery wartościowe dłużne stanowią jedną z lokat dopuszczalnych przy tworzeniu rezerw techniczno-ubezpieczeniowych,

c) określenie to jest używane wielokrotnie w ustawie Prawo dewizowe ${ }^{3}$.

* Autor jest Zastępcą Przewodniczącego Komisji Papierów Wartościowych i Giełd.

${ }^{1}$ Ustawa z dnia 28 sierpnia 1997 r. o organizacji i funkcjonowaniu funduszy emerytalnych (Dz.U. z 1997 r. Nr 139, poz. 934, z późn. zm.).

${ }^{2}$ Ustawa z dnia 28 lipca 1990 r. o działalności ubezpieczeniowej (Dz.U. z 1996 r. $\mathrm{Nr} 11$, poz. 62 , z późn. zm.).

${ }^{3}$ Ustawa z dnia 27 lipca 2002 r. Prawo dewizowe (Dz.U. z 2002 r. Nr 141, poz. 1178). 
Przy tej okazji podkreślić można, że ani ustawa Prawo o publicznym obrocie papierami wartościowymi („PrPapW”), ani ustawa o funduszach inwestycyjnych ${ }^{5}$ nie używają określenia „papiery wartościowe dłużne”. PrPapW używa jedynie określenia „papiery wartościowe opiewające na wierzytelności”. Należy zatem stwierdzić, że papiery wartościowe dłużne są pojęciem doktrynalnym i zdefiniowanie czym są jest zadaniem nauki p rawa. Wydaje się jednak, że intuicyjnie lub raczej wskutek milczącej zgody doktryny, pojęcia „papiery wartościowe dłużne” i „papiery wartościowe opiewające na wierzytelności” są tautologiami. A jakkolwiek można wyobrazić sobie wprowadzenie różnicy pomiędzy tymi pojęciami, zabieg taki pozbawiony byłby praktycznego znaczenia.

\section{DŁUŻNE PAPIERY WARTOŚCIOWE W KODEKSIE CYWILNYM}

Teoretycznie, zdefiniowanie papierów wartościowych dłużnych (opiewających na wierzytelności) należałoby rozpocząć od analizy przepisów kodeksu cywilnego. Analiza przepisów kodeksu cywilnego dotyczących papierów wartościowych, jest jednak przedsięwzięciem mocno dyskusyjnym, przynajmniej oceniając przydatność tej analizy dla potrzeb praktyki. Przepisy ${ }^{6}$ art. $921^{6}-921^{12}$ stanowią niewątpliwie pewien manifest zmian systemu politycznego i gospodarczego, lecz można zasadnie bronić tezy, że tylko taką rolę (manifestu) pełnią w systemie prawa polskiego. Ponieważ nie jest to głównym przedmiotem tego artykułu, przeto zaprezentuję jedynie podstawowe przyczyny, które legły u podstaw tej oceny. Pierwszym elementem rozważań jest fakt popełnienia przez ustawodawcę znaczącego błędu przy systematyce norm dotyczących papierów warto-

\footnotetext{
${ }^{4}$ Ustawa $z$ dnia 21 sierpnia 1997 r. Prawo o publicznym obrocie papierami wartościowymi (Dz.U. z 2002 r. Nr 49, poz. 447 z póź. zm.).

${ }^{5}$ Ustawa z dnia 28 sierpnia 1997 r. o funduszach inwestycyjnych (Dz.U. z 2002 r. Nr 49, poz. 448).

${ }^{6}$ Uchwalone Ustawą z dnia 28 lipca 1990 r. o zmianie ustawy - kodeks cywilny (Dz.U. z 1990 r. Nr 55, poz. 321).
} 
ściowych w k.c. Z przyczyn mi nieznanych przepisy te zlokalizowane są w księdze III, tytule XXXVII, Dziale II tj. obok innych umów nazwanych. Wydaje się wszakże, że wbrew wrażeniu wynikającemu z tej systematyki, nie ma umowy nazwanej „papieru wartościowego" (jakiego zresztą? Na okaziciela, imiennego, na zlecenie, dłużnego czy udziałowego?). Gdyby ustawodawca chciał uregulować np. skrypt dłużny - jako rodzaj nazwanego papieru wartościowego - sytuacja byłaby odmienna, a miejsce zapisania norm właściwe. Fakt, że analizowane przepisy są praktycznie martwe, czyni ten błąd nieszkodliwym dla praktyki. I jakkolwiek prezentuję tu tezę o nieszkodliwości tego błędu, jednak względy estetyczne (jeżeli użyjemy tego słowa dla oceny poprawności legislacyjnej aktu prawnego), wskazują na celowość zmian.

Kodeks cywilny opisuje papiery wartościowe w sposób, który daje pewną namiastkę ich typizacji tj. obok oczywistego podziału na papiery wartościowe imienne, na okaziciela, na zlecenie - wprowadza rozróżnienie na papiery wartościowe, opiewające na wierzytelności, i inne papiery wartościowe. To pierwsze rozróżnienie dokonane jest w oparciu o kryterium sposobu przenoszenia praw. Drugie kryterium podziału tj. na papiery wartościowe opiewające na wierzytelności i pozostałe jest w praktyce jedynie zasygnalizowane i opiera się na założeniu, że terminy te mogą być zastosowane i rozumiane apriorycznie. Tym niemniej nie jest kwestionowane w doktrynie, że podział ten jest dokonany ze względu na rodzaj praw inkorporowanych w danym papierze wartościowym.

\section{POJĘCIE PAPIERU WARTOŚCIOWEGO DŁUŻNEGO W OPOZYCJI DO POJĘCIA PAPIERU WARTOŚCIOWEGO UDZIAEOWEGO, RZECZOWE PAPIERY WARTOŚCIOWE}

Przyjęcie, wzorem kodeksu cywilnego, dychotomicznej systematyki papierów wartościowych tj. podziału na papiery wartościowe dłużne opiewające na wierzytelności) i pozostałe, nie jest jedynym możliwym. Skoro, jak wskazano w poprzednim punkcie, kryterium podziału jest rodzaj praw inkorporowanych $\mathrm{w}$ danym papierze wartościowym, to - 
nawiązując do klasycznych pojęć cywilistyki - wskazać należy na istnienie praw podmiotowych względnych (dłużnych i udziałowych) i bezwzględnych - skutecznych erga omnes. Można np. wzorem niektórych autorów niemieckich zaproponować trójpodział na papiery wartościowe dłużne, rzeczowe (określane też mianem towarowych) i udziałowe $\mathrm{e}^{7}$. Od strony teoretyczno-prawnej przeprowadzenie takiego podziału jest $\mathrm{w}$ prawie polskim moźliwe. Przykładem rzeczowego papieru wartościowego byłyby zatem konosamenty i dowody składowe - papiery wartościowe ucieleśniające prawo do danego towaru ${ }^{8}$. W przypadku dwóch powyższych przykładów rzeczowy charakter tych papierów wartościowych nie jest jednak bezdyskusyjny - niekiedy niezbędne byłoby badanie przesłanki faktycznej - rzeczywistej specyfikacji towaru na statku lub w domu składowym. Dodać jednak należy, że rzeczowe (towarowe) papiery wartościowe poprzez związanie z towarem są ulatwieniem obrotu, lecz stosowane są w praktyce co do zasady między profesjonalistami i nie są st and a ryzowa ne (nie występują w obrocie masowym w serii lub seriach). Waga problemu, konieczność zdefiniowania pojęcia np. dla potrzeb powołanych ustaw, jest zatem ograniczona. Wydaje się jednak, że ze względu na specyfikę tych papierów wartościowych, należy z przyczyn teoretycznoprawnych jak i celowościowych przyjąć, że stanowią one szczególny rodzaj papierów wartościowych. Nawiązując jedynie do kwestii aksjologicznych, trudno byłoby zaakceptować inwestowanie przez fundusz emerytalny, bank lub fundusz inwestycyjny otwarty w konosamenty lub dowody składowe.

7 Por. np. B. RehfeldT - W. Zöllner, Wertpapierrecht. Ein Studienbuch, München 1975, s. 7 i 8 . Autorzy ci nie utożsamiają jednak w pełni papierów wartościowych, opiewających na prawa rzeczowe, z papierami wartościowymi towarowymi. Jako przykład papierów wartościowych rzeczowych podają bowiem np. listy hipoteczne (Hypothekenbriefe), a towarowych - konosament i dowód składowy (Lagerschein). Z analizy tekstu wynika jednak, że papiery wartościowe towarowe są jednak uznawane za pewien podtyp papierów wartościowych rzeczowych (sachenrechtliche Wertpapiere).

${ }^{8}$ Por. dalsze rozważania na ten temat w pkt IVb. 
IV. ANALIZA POSZCZEGÓLNYCH TYPÓW PAPIERÓW WARTOŚCIOWYCH

Nie jest przedmiotem niniejszego artykułu opisywanie metodą podręcznikową poszczególnych typów papierów wartościowych. Celem poniższych rozważań jest ogólne przedstawienie różnych typów papierów wartościowych, zaproponowanie ich typologii, przede wszystkim zaś - szerzej przedstawić te papiery wartościowe, których kwalifikacja jest dyskusyjna.

\section{A. Papiery wartościowe udziałowe}

Papierami wartościowymi o charakterze korporacyjnym (udziafowymi) są te, które dają uprawnionemu prawa wykonywane w organach spółki, lub wykonywane wobe c spółki. W doktrynie wyróżnić też można koncepcję tzw. praw organizacyjnych - czyli wyodrębnionych z praw udziałowych praw o charakterze niemajątkowym. W niniejszym artykule nie przyjmuję tej konwencji. Wręcz przeciwnie - utożsamiam pojęcie praw udziałowych $w$ znacznej mierze $\mathrm{z}$ tym, co określane bywa jako prawa organizacyjne, prawa majątkowe uznając za prawa o charakterze dłużnym, a nie za element praw udziałowych. Zgadzam się tu raczej z rozumieniem M. Michalskiego, że „papiery wartościowe udziałowe ucieleśniają prawa podmiotowe, wyznaczające pozycję akcjonariusza w spółce akcyjnej”'10 (a nie roszczenia majątkowe wobec spółki akcyjnej - A.Ch.). Jakkolwiek odgraniczenie tych praw i obowiązków od niektórych innych może budzić wątpliwości (sporny jest np. charakter prawny obowiązku wezwania na akcje jako obowiązku akcjonariusza wobec innych akcjonariuszy lecz realizowanego poza spółką), zakwalifikowanie pewnych ich kategorii, jako praw udziałowych, jest bezporne.

${ }^{9}$ Por. T. SoJKA, Charakter prawny świadectwa użytkowego, «Prawo Papierów Wartościowych» $2001 \mathrm{nr} 10, \mathrm{~s} .33$.

${ }^{10} \mathrm{M}$. MiChalski, Pojęcie „dokumentu akcji” a pojęcie akcji w Kodeksie spótek handlowych, «Prawo Papierów Wartościowych» $2001 \mathrm{nr} 8$, s. 3. 
Przykładowo - prawo głosu, realizowane na WZA wątpliwości takich nie budzi.

Pamiętać jednak należy, chociaż fakt ten jest niedoceniany, że akcje są zróżnicowane nie tylko na poziomie różnych typów akcji w spółce akcyjnej, ale i różnych typów akcji w zależności od osoby prawnej. Istotne jest bowiem rozróżnienie pomiędzy akcjami stanowiącymi tytuł uczestnictwa w spółce akcyjnej a akcjami stanowiącymi tytuł uczestnictwa w spółce komandytowo-akcyjnej. Paradoksalnie, akcje w spółce komandytowo-akcyjnej ze względu na mniejszy realnie wpływ na zarządzenie spółką są nieco bliższe papierom wartościowym dłużnym, pozostają jednak, ze względu na wiodący element korporacyjny, papierami wartościowymi o charakterze korporacyjnym. Niezależnie jednak od tego, czy przedmiotem naszych rozważań są akcje spółki akcyjnej czy komandytowo-akcyjnej inkorporują one obok praw udziałowych również prawa o charakterze bezpośrednio lub potencjalnie dłużnym.

Wyodrębnienie tych dwóch kategorii, tj. praw dłużnych bezpośrednio lub potencjalnie, dokonuje się według następującego kryterium: prawa potencjalnie dłużne to takie, które związane $\mathrm{z}$ danym papierem wartościowym nie dają uprawnionemu roszczenia o spełnienie określonego świadczenia. Roszczenie to pojawia się po spełnieniu określonych warunków i wówczas prawa te uzyskują charakter bezpośredni - tj. postać określonego roszczenia. Przykładowo: prawo do dywidendy, formalnie związane $\mathrm{z}$ akcją, ma postać roszczenia akcjonariusza wobec spółki jedynie wtedy, gdy spółka ta osiągnie zysk, przeznaczony uchwałą walnego zgromadzenia akcjonariuszy do podziału między akcjonariuszy.

Podobny charakter ma prawo poboru lub prawo do sumy likwidacyjnej. Opisywaną sytuację odróżnić należy od sytuacji roszczenia o odsetki w przypadku np. obligacji. Pomijając szczególne postacie tego papieru wartościowego, np. niżej opisywane obligacje przychodowe, wskazać należy, że np. prawo do odsetek od początku ma charakter wierzytelności, jakkolwiek prawo do żądania spełnienia świadczenia obligatariusz uzyskuje od chwili, gdy zgodnie $\mathrm{z}$ warunkami emisji może domagać się od emitenta wypłaty określonej sumy 
pieniężnej. Dla porównania - prawo do dywidendy przed jej uchwaleniem nie jest wierzytelnością przysługującą akcjonariuszowi wobec spółki, tym bardziej nie ma zatem postaci roszczenia. Nie ulega jednak wątpliwości, że z papierami wartościowymi udziałowymi mogą być związane roszczenia o spełnienie określonego świadczenia pieniężnego, skierowane do emitenta tych papierów wartościowych. Jeżeli zatem nie chcemy doprowadzić do zatarcia się różnić między doktrynalnie i systemowo odmiennymi pojęciami (tj. papierami wartościowymi dłużnymi i udziałowymi) musimy zaakceptować dosyć oczywistą tezę, że inkorporowanie w papierze wartościowym udziałowym określonych wierzytelności, występujących również w przypadku papierów wartościowych dłużnych, nie jest wystarczającą przesłanką do zmiany kwalifikacji tego papieru wartościowego i uznania go za papier dłużny.

B. Papiery wartościowe rzeczowe (towarowe)

Z systemowego punktu widzenia żadne przepisy nie odwołują się do pojęcia papierów wartościowych opiewających na prawa rzeczowe. Powstaje zatem pytanie o cel i sens dokonania takiego wyodrębnienia - jak również o kryteria takiego wyodrębnienia. Na pozór wystarczającym i podstawowym kryterium jest to, że świadczenie $\mathrm{z}$ danego papieru wartościowego ma charakter rzeczowy - dokonuje się w określonych rzeczach a nie w pieniądzach. Jednak takie ujęcie tego kryterium nie jest słuszne. Zgodnie z funkcjonującymi definicjami i sposobem rozumienia niektórych papierów wartościowych zarówno obligacja ze świadczeniem niepieniężnym, jak i niektóre typy praw pochodnych spełniałyby to kryterium. Słusznie zatem zwraca uwagę M.H. Koziński, że towarowe papiery wartościowe powinny dawać prawo do rozporządzania towarami ${ }^{11} \mathrm{i}$ pozostawać w związku z określonymi umowami (np. umową składu,

${ }^{11}$ M. BĄCZYK - M.H. KozIŃSKI - M. MiChALSKI - W. PYZIOZ - A. SZUMAŃSKI I. WeIss, Papiery wartosciowe, Kraków 2000, s. 451 i n. 
umową przewozu morskiego etc.). Idąc krok dalej, pozostając w zgodzie w przytoczonym poglądem, można twierdzić, że towary, z którymi dany papier wartościowy jest związany, powinny być wyspecyfikowane i związane $\mathrm{z}$ danym papierem wartościowym.

Powyższe rozważania nie mają nic wspólnego z koncepcją uznawania papierów wartościowych za prawa skuteczne erga omnes ${ }^{12}$. Poglądu tego nie podzielam, utożsamia ona bowiem rozszerzenie skuteczności dochodzenia zobowiązań z papierów wartościowych przez osoby nimi się legitymujące $\mathrm{z}$ istnieniem nieograniczonego kręgu zobowiązanych (a tym zobowiązanym jest co do zasady jedynie wystawca/emitent danego papieru wartościowego). Najbardziej typowymi papierami wartościowymi towarowymi są, jak już wspomniano wyżej, konosament i dowód składowy. Jak wynika z przepisów kodeksu morskiego (art. 131) konosament stanowi dowód przyjęcia ładunku w nim oznaczonego na statek w celu przewozu i jest dokumentem legitymującym do dysponowania tym ładunkiem, i do jego odbioru. Ponadto konosament może być przeniesiony na inną osobę, która przez przeniesienie nabywa uprawnienia do dysponowania ładunkiem i do jego odbioru. Dowód składowy z kolei skonstruowany jest na zasadach określonych w przepisach ustawy o domach składowych oraz o zmianie kodeksu cywilnego, kodeksu postępowania cywilnego i innych ustaw ${ }^{13}$. Dowód składowy wydaje składającemu na jego żądanie dom składowy. Dowód składowy, odłączony z księgi składowej, składa się z dwóch, połączonych ze sobą, lecz dających się oddzielić części: $z$ rewersu (składowego dowodu posiadania) i warrantu (składowego dowodu zastawniczego). Obie części dowodu składowego można przenosić przez indos łącznie albo oddzielnie. Jeżeli wystawiono dowód składowy, do przeniesienia własności rzeczy złożonych na skład konieczne jest wręczenie rewersu. Z kolei posiadacza

${ }^{12}$ A. SzUMAŃSKI, Problem dopuszczalności emisji nowych typów papierów wartościowych. $Z$ problematyki zasady 'numerus clausus' papierów wartościowych $w$ prawie polskim, [w:] Księga pamiątkowa ku czci Profesora Stanistawa Wtadyki, Kraków 1996, s. 427 i n.

${ }^{13}$ Dz.U. z 2000 r. Nr 114, poz. 1191. 
rewersu, wykazującego swoje prawo nieprzerwanym szeregiem indosów, uważa się za właściciela rzeczy złożonych na skład. Ponadto rzeczy złożone na skład, na które wystawiono dowód składowy oraz prawa przysługujące posiadaczowi rewersu lub warrantu na tych towarach, nie podlegają egzekucji, a przedmiotem egzekucji może być tylko dowód składowy lub jedna z jego części.

Oba powyższe przykłady dobitnie wskazują na specyfikę towarowych papierów wartościowych i zasadność odmiennego ich traktowania, jak również prowadzą do tezy, że towarowe papiery wartościowe nie są papierami wartościowymi dłużnymi i stanowią odrębną kategorię papierów wartościowy ch. Nie są również papierami wartościowymi udziałowymi.

C. Papiery wartościowe dłużne

a) Obligacje

Teoretycznie, najbardziej typowym papierem wartościowym dłużnym są obligacje. Już jednak po pobieżnej analizie niektórych typów tego papieru wartościowego powstać mogą pewne wątpliwości. Zgodnie $\mathrm{z}$ przepisami ustawy o obligacjach, obligacja jest papierem wartościowym emitowanym w serii, w którym emitent stwierdza, że jest dłużnikiem właściciela obligacji (obligatariusza) i zobowiązuje się wobec niego do spełnienia określonego świadczenia. Świadczenie to może mieć charakter pieniężny lub niepieniężny. Jakkolwiek w typowym przypadku emitent obligacji zobowiązany jest do zwrotu włożonego przez obligatariusza kapitału z odsetkami - możliwe jest również, że w zamian za zwrot kapitału obligatariusz otrzyma jakieś inne świadczenie np. usługę, rzecz lub prawo.

Możliwe jest ponadto, że wartość świadczeń uzyskanych przez obligatariuszy w zamian za to, co zostało świadczone, będzie inna (np. znacznie niższa), aniżeli to, co było przez nich świadczone. W tych najbardziej jaskrawych przypadkach powstaje wręcz pytanie, czy tego typu obligacje nie stanowią jakiegoś szczególnego rodzaju papierów wartościowych nie mieszczących się w kategorii pa- 
pierów wartościowych dłużnych. Szczególnymi przypadkami obligacji są tzw.:

1) obligacje zamienne, które dają prawo do ich zamiany na akcje,

2) obligacje z prawem pierwszeństwa, które umożliwiają nabycie akcji z pierwszeństwem przez dotychczasowych akcjonariuszami spółki,

3) obligacje $z$ prawem do udziału w zysku spółki,

4) obligacje przychodowe, polegające na tym, że emitent ogranicza w treści obligacji swoją odpowiedzialność za zobowiązania wynikające $\mathrm{z}$ tych obligacji do kwoty przychodów lub wartości majątku przedsięwzięcia, do których obligatariuszowi służy prawo pierwszeństwa. Obligacje te mogą przyznawać obligatariuszowi prawo do zaspokojenia swoich roszczeń z pierwszeństwem przed innymi wierzycielami emitenta:

* $\mathrm{z}$ całości albo z części przychodów lub z całości albo części majątku przedsięwzięć, które zostały sfinansowane ze środków uzyskanych z emisji obligacji lub

* z całości albo z części przychodów z innych przedsięwzięć określonych przez emitenta.

Emitentami obligacji przychodowych może być jedynie ograniczony krąg podmiotów - w szczególności jednostki samorząa terytorialnego, jak również spółki akcyjne i spółki z o.o., powiązane $\mathrm{z}$ jednostkami samorządowymi kapitałowo lub poprzez koncesje lub wykonywane zadania o charakterze użyteczności publicznej.

Niezwykle szeroka definicja pojęcia obligacji pozwala nawet na postawienie pytania o możliwość emisji obligacji, w warunkach której określono, że zwrot świadczenia głównego nie jest w ogóle konieczny (np. tzw. „wieczne obligacje” emitowane czasami na zagranicznych rynkach finansowych). Jest to problem dyskusyjny i wykraczający poza ramy tematyczne niniejszego tekstu - jest to kwestia analizy - czy tego typu ukształtowanie treści obligacji nie jest sprzeczne z naturą tego stosunku prawnego. W mojej opinii nie, lecz jedynie pod warunkiem precyzyjnego ukształtowania stosunku prawnego - tj. takiego który stwierdza, że zobowiązanie emitenta nie może być nieograniczone czasowo i musi on mieć możliwość wypowiedzenia umowy tj. „zamknięcia” relacji prawnych między nim a obli- 
gatariuszem. Przy czym powinno to nastąpić albo po upływie określonej liczby okresów odsetkowych, albo za zapłatą określonej sumy.

\section{b) Listy zastawne}

Wśród listów zastawnych wyróżnić można kategorie hipotecznego i publicznego listu zastawnego. Hipoteczny list zastawny jest papierem wartościowym imiennym lub na okaziciela, którego podstawę emisji stanowią wierzytelności banku hipotecznego zabezpieczone hipotekami. Z kolei publiczny list zastawny jest papierem wartościowym imiennym lub na okaziciela, którego podstawę emisji stanowią wierzytelności banku hipotecznego z tytułu kredytów zabezpieczonych przez instytucje publicznoprawne polskie i międzynarodowe, jak również kredyty udzielone takim instytucjom.

Listy zastawne uprawniają do świadczeń pieniężnych, które polegają na wypłacie odsetek i wykupie tych papierów wartościowych. Wbrew nazwie, sugerującej pewne powiązania $\mathrm{z}$ papierami wartościowymi towarowymi (opiewającymi na prawa rzeczowe), listy zastawne są typowymi papierami wartościowymi dłużnymi - wszelkie elementy prawno-rzeczowe dotyczą bowiem tylko jednej z kategorii tych papierów wartościowej (hipotecznych listów zastawnych) i to jedynie w sferze zabezpieczeń.

c) Bankowe papiery wartościowe

Bankowe papiery wartościowe to również typowe papiery wartościowe dłużne służące gromadzeniu przez banki środków pieniężnych w złotych lub w innej walucie wymienialnej. Sposób legislacyjnego ukształtowania tych papierów wartościowych może spowodować pewne wątpliwości zwłaszcza w zakresie ich typologii. Nie jest w szczególności do końca jasne, czy przepisy o bankowych papierach wartościowych zawarte w ustawie Prawo bankowe tworzą jeden, szczególny, nazwany typ papieru wartościowego („bankowy papier wartościowy”) czy też w zakresie szeroko rozumianej instytucji „bankowego papieru wartościowego” możliwa jest kreacja 
różnego typu papierów wartościowych. Wbrew głoszonym czasem w literaturze poglądom skłaniam się do uznania bankowego papieru wartościowego za typ nazwany papieru wartościowego. Pogląd ten uzasadnić można dwoma argumentami: legislacyjnym i porównawczym ${ }^{14}$. Argument legislacyjny wyprowadzam z art. 90 Prawa bankowego. Zgodnie $\mathrm{z}$ tym przepisem bankowy papier wartościowy zawiera w nazwie wyrazy „bankowy papier wartościowy”. Przepis ten określa również bardzo dokładnie treść papieru - pomijając oczywiście bankowy papier w formie zdematerializowanej dopuszczalny również w prawie bankowym. Jest to typowy zabieg legislacyjny zmierzający do określonej kategorii nazwanego papieru wartościowego (por. regulacje weksli, czeków lub obligacji).

Nasuwający się - jako podstawowy - argument, że bankowy papier wartościowy może być ukształtowany w sposób bardzo różny (np. różne waluty, terminy płatności i wypłaty odsetek) łatwo obalić wskazując, że np. zakres możliwych regulacji obligacji ujęty być może znacznie szerzej. Można by oczywiście wysuwać tezę, że ustawodawca uznał, że numerus clausus istnieje w ramach obligacji i bankowych papierów wartościowych, przypominałoby to jednak nieco zdefiniowanie koloru w modelu Forda $\mathrm{T}^{15}$. Trawestując to znane powiedzenie: „może być dowolna obligacja, pod warunkiem że byłaby obligacją". Niezależnie od powyższych dywagacji bankowy papier wartościowy pozostaje typowym papierem wartościowym dłużnym - nie inkorporuje żadnych praw o charakterze prawnorzeczowym lub udziałowym.

d) Inne papiery wartościowe dłużne

Ponieważ celem tego artykułu nie jest opis wszelkiego typu papierów wartościowych, wspomnieć jedynie można o innych postaciach ty-

${ }^{14}$ Podobnie M. MichalsKI, Konstrukcje bankowych papierów wartościowych $w$ świetle zasady numerus clausus papierów wartościowych w prawie polskim, «Prawo Bankowe» 1998 nr 2, s. 43 i n.

${ }^{15}$ Jak mówił Henry Ford - „Ford może mieć każdy kolor, pod warunkiem, że jest to kolor czarny". 
powych papierów wartościowych dłużnych, które wydają się nie rodzić szczególnych wątpliwości z punktu widzenia tematu tego artykułu. Papierami tymi są np. skarbowe papiery wartościowe, weksle i czeki.

D. Papiery wartościowe dłużne hybrydalne

Szczególnie ciekawymi, z punktu widzenia niniejszego artykułu, są papiery wartościowe wykazujące znaczne nasycenie elementów korporacyjnych lub quasi korporacyjnych. Te papiery wartościowe są jednocześnie ważnym źródłem lokat dla funduszy emerytalnych $\mathrm{i}$ innych podmiotów dokonujących lokat w papiery wartościowe. Papierami wartościowymi najbardziej dyskusyjnymi są kwity depozytowe i niektóre podtypy certyfikatów inwestycyjnych.

\section{a) Kwity depozytowe}

Kwitem depozytowym jest papier wartościowy wystawiony przez instytucję finansową (z siedzibą na terytorium Rzeczypospolitej Polskiej, państwa członkowskiego lub państwa należącego do OECD) poza terytorium Rzeczypospolitej Polskiej w związku z akcjami dopuszczonymi do publicznego obrotu albo akcjami wyemitowanymi poza tym terytorium, albo na terytorium Rzeczypospolitej Polskiej w związku z akcjami wyemitowanymi poza tym terytorium. Kwit depozytowy emitowany jest na podstawie pisemnej umowy z emitentem akcji zapewniającej możliwość zamiany tego papieru wartościowego na akcje w proporcji określonej w umowie, przejście na właściciela tego papieru wartościowego praw majątkowych stanowiących pożytki $z$ akcji lub ich równowartości oraz możliwość wydania przez właściciela tego papieru wartościowego jego wystawcy wiążącej dyspozycji co do sposobu głosowania na walnym zgromadzeniu akcjonariuszy. Celem emisji kwitów depozytowych jest umożliwienie przez podmioty zagraniczne (z punktu widzenia siedziby emitenta) nabywanie i obrót papierami wartościowymi inkorporującymi pośrednio prawa z papierów wartościowych, stanowiących podstawę emisji kwitów depozytowych - na lokalnym rynkach tych podmiotów. 
Ustawodawca w sposób wyraźny włącza pojęcie kwitu depozytowego do pojęcia papierów wartościowych udziałowych. Zgodne z przepisem art. 150 PrPapW obowiązki informowania o nabywaniu lub zbywaniu znacznych pakietów akcji stosuje się odpowiednio w przypadku nabycia lub zbycia obligacji zamiennych na akcje spółki publicznej, kwitów depozytowych, jak również innych papierów wartościowych, z których wynika prawo lub obowiązek nabycia akcji spółki publicznej. Ustawodawca, w pewnym zakresie, uznaje zatem kwity depozytowe za równoważne akcjom. Zgodnie $\mathrm{z}$ przepisem art. 158a PrPapW kwity depozytowe wystawione w związku Z akcjami spółki publicznej uważa się za papiery wartościowe uprawniające do wykonywania prawa głosu $\mathrm{z}$ takiej liczby akcji tej spółki, jaką posiadacz kwitu depozytowego może uzyskać w wyniku zamiany kwitów depozytowych na te akcje.

Charakterystyczną cechą kwitu depozytowego jest zatem możli wość pośredniego wykonywania praw o charakterze k or por a cyjny m. Ze względu na ocenę charakteru prawnego tego papieru wartościowego podkreślenia wymaga owa pośredniość wykonywania praw korporacyjnych. Ponieważ papier wartościowy inkorporuje pewne relacje o charakterze kontraktowym, pamiętać należy, że wszelkie wykonywanie obowiązków o charakterze korporacyjnym to realizacja obowiązków o charakterze kontraktowym przez osobę uprawnioną $\mathrm{z}$ papieru wartościowego udziałowego (np. akcji) wobec posiadacza kwitu depozytowego. Oznacza to, że posiadacz kwitu depozytowego nie ma żadnego prawa udziałowego skutecznego wobec spółki, lecz jedynie prawo do żądania określonego zachowania (świadczenia) od emitenta kwitu depozytowego. Wynika z tego, że pomimo stosowanych przez ustawodawcę fikcji prawnych - kwit depozytowy jest dłużnym papierem wartościowym.

b) Certyfikaty inwestycyjne

Certyfikaty inwestycyjne to papiery wartościowe emitowane przez fundusze inwestycyjne zamknięte, mieszane i zamknięte spe- 
cjalistyczne. Co do zasady inkorporują one uprawnienia ich posiadaczy związane $\mathrm{z}$ uczestnictwem w funduszach inwestycyjnych. Certyfikaty inwestycyjne danego funduszu reprezentują jednakowe prawa majątkowe. Swoboda umarzania certyfikatów, w zależności od typu funduszu, wiąże się $\mathrm{z}$ różnego typu ograniczeniami. Certyfikaty inwestycyjne w funduszu inwestycyjnym zamkniętym uprawniają ich posiadacza, o ile posiada je w liczbie co najmniej 5\% wyemitowanych, do uczestnictwa w radzie inwestorów będącej organem kontrolnym funduszu. Rada inwestorów kontroluje realizację celu inwestycyjnego funduszu inwestycyjnego zamkniętego i polityki inwestycyjnej oraz przestrzeganie ograniczeń inwestycyjnych. W tym celu członkowie rady inwestorów mogą przeglądać księgi i dokumenty funduszu oraz żądać wyjaśnień od towarzystwa.

Ponadto w przypadku stwierdzenia nieprawidłowości w realizowaniu celu inwestycyjnego, polityki inwestycyjnej lub w przestrzeganiu ograniczeń inwestycyjnych, rada inwestorów wzywa towarzystwo do niezwłocznego usunięcia nieprawidłowości oraz zawiadamia o nich Komisję Papierów Wartościowych i Giełd. Rada inwestorów może również, w przypadkach wskazanych w statucie, postanowić o rozwiązaniu funduszu inwestycyjnego zamkniętego. Rada inwestorów rozpoczyna działalność, gdy zechce w niej uczestniczyć co najmniej trzech uczestników posiadających co najmniej 5\% liczby certyfikatów każdy. Z kolei w specjalistycznych funduszach inwestycyjnych zamkniętych funkcjonują certyfikaty dające prawo do głosu na tzw. zgromadzeniu inwestorów. Statut funduszu może określać, że certyfikaty inwestycyjne imienne są uprzywilejowane w zakresie prawa głosu, $z$ tym że jednemu certyfikatowi można przyznać nie więcej niż dwa głosy. $Z$ formalnego punktu widzenia wyżej opisane papiery wartościowe mieszczą się w kategorii udziałowych papierów wartościowych. Dają one bowiem prawo do udziału i wykonywania praw głosu w organach osób prawnych. Można zatem uznać, że certyfikaty inwestycyjne funduszu zamkniętego i specjalistycznego zamkniętego są papierami wartościowymi udziałowymi. Obraz ten komplikują dwie kwestie - po pierwsze, kwestia dochodu i wypłaty tego dochodu; po drugie, uprawnienie do żądania umorzenia, przy- 
sługujące posiadaczowi certyfikatu inwestycyjnego funduszu mieszanego względem jego emitenta. Podsumowując wydaje się, że certyfikaty inwestycyjne funduszu mieszanego są papierami wartościowymi dłużnymi ${ }^{16}$, podczas gdy certyfikaty inwestycyjne pozostałych typów funduszu (zamkniętego i specjalistycznego zamkniętego) mają charakter papierów wartościowych udziałowych.

\section{E. Prawa pochodne}

Zgodnie z przepisem art. 3 ust. 3 PrPapW prawa pochodne to papiery wartościowe, których cena zależy bezpośrednio lub pośrednio od ceny papierów wartościowych, o których mowa w art. 32 ust. 1 i 2 PrPapW. Podstawowymi typami praw pochodnych w obrocie są opcje, warranty i transakcje terminowe. Stworzenie jednolitej, pełnej definicji praw pochodnych wydaje się niemożliwe podobnie jak prezentacja możliwych podziałów. Rozgraniczyć jednak należy szczególnie prawa pochodne $\mathrm{z}$ rozliczeniem rzeczywistym i prawa pochodne $z$ rozliczeniem finansowym. W zależności od rodzaju prawa pochodnego świadczeniem $\mathrm{z}$ praw pochodnych $\mathrm{z}$ rozliczeniem rzeczywistym jest przeniesienie określonej własności rzeczy lub też pieniędzy. Niezależnie jednak od tego, czy mamy do czynienia z dostawą fizyczną czy $z$ rozliczeniem gotówkowym, istnienie praw pochodnych nie jest uzależnione od tego, czy osoba zobowiązana posiada czy też nie posiada tzw. instrument bazowy. Teza ta jest oczywista w przypadku praw pochodnych $\mathrm{z}$ rozliczeniem gotówkowym, gdzie instrument bazowy jest jedynie wyznacznikiem wartości świadczenia.

${ }^{16}$ Natura prawna certyfikatów inwestycyjnych w prawie niemieckim jest bardziej sporna. Są one bowiem uważane przez część doktryny za papiery wartościowe rzeczowe. Wynika to jednak ze specyfiki uregulowań niemieckich, a w szczególności z faktu, że jednym $\mathrm{z}$ rozwiązań konstrukcji funduszu inwestycyjnego jest tzw. rozwiązanie współwłasnościowe (Miteigentumslösung). W rozwiązaniu tym posiadaczowi certyfikatu przysługuje formalnie prawo współwłasności - na zasadach zbliżonych do polskiej wspólności łącznej) portfela papierów wartościowych funduszu. Por. B. REHFELDT - W. ZöllnER, op. cit., s. 8. 
Prawa pochodne nie zaliczają się zatem do tzw papierów wartościowych towarowych (rzeczowych), nie inkorporują również i praw udziałowych. Wydawać by się zatem mogło, że są one (prawa pochodne) typowymi papierami wartościowymi dłużnymi. Jednak takie jednorodne podejście wydaje się być błędne. Biorąc pod uwagę ich funkcję i typowe postacie wyróżnić można papiery wartościowe, które charakteryzują się tym, że w ich konstrukcji przewidzieć można emitenta (np. warranty opcyjne) i takie, w których nie można go zidentyfikować (klasyczne opcje i transakcje terminowe). W przypadku transakcji terminowych, zwłaszcza tych $\mathrm{z}$ rozliczeniem finansowym, każda osoba, będąca stroną takiej transakcji, może znajdować się na pozycji krótkiej i na pozycji długiej (być zobowiązana lub uprawniona), przy czym stan ten może się zmieniać wielokrotnie w czasie, gdy umowa jest zawarta. Biorąc zatem pod uwage powyższe czynniki, analizując również funkcje ekonomiczne praw pochodnych, uznać można, że prawa pochodne nie są papierami wartościowymi dłużnymi - przynajmniej w znaczeniu, jakie nadaje ustawodawca temu pojęciu w większości ustaw, gdzie ono funkcjonuje. Do praw pochodnych klasyczne podziały nie znajdują zastosowania, same zresztą prawa pochodne są uważane za papiery wartościowe jedynie jako wynik pewnej konwencji, przyjętej i stosowanej jedynie na gruncie PrPapW.

\section{PAPIERY WARTOŚCIOWE DŁUŻNE - WNIOSKI}

Ustawodawca, posługując się pojęciem papierów wartościowych dłużnych, nie definiuje explicite konkretnych typów papierów wartościowych (np. obligacji) jako dłużnych właśnie. Podporządkowanie ich zatem do określonego podtypu papierów wartościowych dłużnych nastąpić może jedynie w drodze analizy pojęcia i interpretacji prawa. Zdefiniowanie charakteru prawnego niektórych typów papierów wartościowych o charakterze hybrydowym (tj. łączących cechy papierów wartościowych dłużnych i udziałowych) jest zadaniem niełatwym. Poniżej chcę przedstawić ogólne wnioski wypływające z powyższych rozważań: 
1) Po pierwsze, jeżeli w danym papierze wartościowym współistnieją elementy o charakterze udziałowym i o charakterze dłużnym, papier ten powinien być uważany za papier wartościowy udziałowy.

2) Fakt, że dany papier wartościowy daje uprawnienie do zamiany go na papier wartościowy udziałowy, jak również że stanowi konstrukcję pozwalającą jego posiadaczowi uzyskiwać ekonomiczne korzyści równoważne wynikającym z papieru wartościowego powiązanego - nie wyłącza dłużnego charakteru tego (zamienianego) papieru.

3) Możliwość wykonywania w sposób zbiorowy niektórych uprawnień z papieru wartościowego, w szczególności poprzez użycie formy uchwały (np. zgromadzenia obligatariuszy w niektórych systemach prawnych lub rady inwestorów w funduszu inwestycyjnym zamkniętym), nie wyłącza dłużnego charakteru danego papieru wartościowego.

4) Wyróżnikiem pozwalającym na określenie papieru wartościowego jako papieru wartościowego dłużnego jest to i jedynie to, czy posiadaczowi papieru wartościowego przysługuje wobec emitenta roszczenie o odkupienie (wykupienie, umorzenie) danego papieru wartościowego. Istotne jest, że kwota wykupu nie musi być tożsama z wartością nominalną danego papieru wartościowego. W pewnych okolicznościach kwota ta może być nawet niższa. Istnienie lub nie w konstrukcji papieru wartościowego świadczeń o charakterze dłużnym lub korporacyjnych nie ma decydującego znaczenia $z$ punktu widzenia oceny charakteru prawnego papieru wartościowego jako papieru dłużnego.

Mam oczywiście świadomość, że stosunkowo krótki artykuł nie może dać pełnej odpowiedzi na pytanie w nim postawione tj. o charakter prawny papieru wartościowego dłużnego. Tezy postawione w artykule należy zatem traktować jedynie jako hipotezę roboczą, która powinna być zweryfikowana w toku dalszej dyskusji. 


\section{Definition of Debt Securities}

\section{Summary}

The main subject of this article is the definition of debt securities in Polish civil law. This expression („debt securities”) used in many parliaments bills, was not defined on the level of the parliaments bill. Especially in cases of so called "hybrid securities" (securities with the mixed legal nature) there is a necessity to analyze and define their legal nature. This article gives a very short overview on the different types of securities and proposes their systematical classification. The main conclusion of this article is: either in the case of the mixed nature of securities, the right to demand from the issuer to withdraw securities (to pay for them or exchange them into a different type of securities) determines the legal nature of securities as debt securities. 